staff is obviously very much alive to current economic problems; but it is equally concerned with the fundamental considerations that these problems raise. Only a very few of the investigations can be mentioned here; but they exemplify the diversity of the work.

The maximum transpiration of water by plants, and therefore the deficit of soil water, can be calculated from meteorological data; experiments are recorded which show that the irrigation of sugar beet in a dry summer gave the most satisfactory results when the amount of irrigation water was based on these calculations. In the study of the heat balance of soil, it is shown that in the south of England only small amounts of solar energy are used, at any rate in some parts of the year, in warming the soil, and as much as a half may be used in transpiration. Further work is planned on the heat balance of the soil.

Much work is devoted to the composition of the soil. Its mineralogy and the way in which nutritional elements are held in the crystal structure of clay are being studied. The reduction in soil under aerobic conditions has been shown to involve micro-organisms. Spectrographic work on soils, particularly-at the moment-in connexion with molybdenum, has just begun.

Methods of counting the micro-organic population of the soil continue to be investigated. Microscope counts on the Broadbalk soils show higher numbers of both bacteria and actinomyces in the farmyard manure plot than in either the unmanured or complete 'artificial' plot, where the numbers are not very different.

Recent discussions on nitrification add to the importance of the study of this subject at Rothamsted. In particular, it is interesting to note that a pure uncontaminated culture of Nitrosomonas oxidizes ammonia as efficiently as the crude culture. The possibility of antibiotic control of fungal diseases of roots - at the moment the control of Fusarium by certain actinomyces-is under examination. There is also a good deal of work on the nodule organism, Rhizobium.

The use of fertilizers, although a long-standing practice now, still calls for much work and for work requiring much patience. At Rothamsted the rates at which some nutritional elements are taken up, the most efficient placing of fertilizers and many other matters concerning the economic use of fertilizers are being investigated in field experiments. Important work has been commenced in connexion with this work on the use of radioactive tracers whereby the movements of elements can be determined. The reaction between excised roots and nutrient solutions, which has already been studied considerably in the United States and in Sweden, is a part of the Rothamsted programme. Among other things this work seems to show that the rate of uptake of fertilizer elements is dependent upon the carbohydrate content of the roots. The examination of the rate of respiration, in relation to uptake from solution, is likely to give some important results.

The spraying of the leaves of some plants with sugar solutions under certain conditions confirms the conclusions of others that there is an increase in the dry weight of the plant. The explanation of this, however, does not seem to be quite simple and is being investigated. There is some very well-controlled work on germination which already shows, among other things, that there is a well-defined moisture potential below which seeds cannot germinate.
The electron microscope has been improved and is used in a number of investigations, among them the study of viruses and the determination of their size and shapes. Considerable work is being done on potato leaf roll and on some diseases of sugar beet. Laboratory work on these subjects is combined with field-work in which some of the spraying tests look like giving useful results.

Considerable research is being done on nematology. This is comparatively new work, and it is good that the staff concerned are adding to their many investigations some instruction in plant and soil nematodes. They recently conducted a course at Cambridge, and a book on laboratory methods has been issued and an earlier book revised. A study of the migration of the potato eelworm has been begun, and in the fieldwork the influence of soil fumigants and of humidity is being examined.

'The migration of insects and the fluctuations of insect populations are being studied, and the relationships found between insect populations and weather are likely to have practical significance. The habits of bees in seeking food is a study that will be of value to bee-keepers.

The statistical work at Rothamsted not only serves all departments in the design of work and the interpretation of results, but also is involved in collaborative work both in Great Britain and overseas. Sample surveys were carried out with maincrop potatoes and of marginal land.

There is no space adequate to summarize the two special reports named at the beginning of this note; and the work of the farms at Rothamsted and Woburn, important as it is and covering a wide range, can only be mentioned. A special interest in these reports for 1949 is in the long summer drought, which seems to have had little effect on cereals but to have retarded the root crops.

\section{MARINE BIOLOGY IN GREAT BRITAIN}

$T$ HE September number of the Journal issued by the Marine Biological Association of the United Kingdom contains ten papers of varied fare for marine biologists.

The population dispersion of Tellina tenuis in the Exe Estuary was studied by Mr. N. A. Holme, who found that there was uniform distribution, with a spacing of about one inch. An artificial increase in numbers within an enclosed area resulted in the dispersal of the individuals, suggesting a correlation between position and the movements of the long inhalent siphons of the molluses during feeding. Distribution relative to age and size was not considered, as in Stephen's Millport counts. It is interesting to record, however, that weather conditions markedly affect the Tellina population. Continued gales churning up the sand in Kames Bay completely upset the expected counts in September last year.

Messrs. E. W. Knight Jones and J. P. Stevenson investigated the gregarious tendency during settlement of the New Zealand barnacle Elminius modestus, which has settled for good in Great Britain and has spread rapidly along the south and south-east coasts, where it is a serious competitor for space with the spat on oyster beds. The cyprids settled in groups, 
especially when recently fixed barnacles were present. This suggests an olfactory stimulus which can act at a distance. The range of dispersal is probably not great, since heavy settlement occurred only near previous barnacle groups. It is known that the cypris stage makes exploratory campaigns before finally settling.

That the larvæ of some worms are sensitive to the physical nature of the substratum on which they settle was admirably shown by Wilson (1948). Messrs. H. Barnes and H. T. Powell have studied the settlement of barnacle and Pomatoceros larvæ on several types of glass fibre cloth, and found that these larvæ will not attach themselves to a staple cloth from which short fibres project in 1-mm. lengths, though they will do so on a smooth or continuous cloth from which the long fibres do not project. Tubularia larynx, however, is unaffected by the variation in the surfaces of the cloths tested.

Dr. J. A. C. Nicol has worked on the responses of Branchiomma vesiculosum to light. These tube worms live in groups in dark niches at extreme low tide, and in shallow water in estuaries. The branchial crown expands in light and in darkness, though feeding occurs during the day-time, the branchiæ being then turned towards the light. A worm removed from its tube turns away from the light. Response is most sensitive in weak light, to a decrease in light intensity but not to an increase, and to moving intensity changes such as the passing of a shadow, though the worms tire after repeated stimulation. It is suggested that the reaction to photic stimuli is partly a feeding response and partly a means of evading the attacks of predaceous flatfish, such as the sole and lemon dab, which bite off the branchial crown of an expanded worm.

The life-history of many of the commonest marine animals is still imperfectly known, and it is surprising that Nereis diversicolor should have been one of these, until Dr. R. Phillips Dales studied its breeding habits on the Essex coast. Artificial fertilization provided the early stages up to the young chætigerous larvæ, which could then be recognized from filtered water in trenches dug in the muddy area in which the adult worm lives. Spawning occurred in the middle of February, the weak trochophores developing chætæ when about two weeks old, and living in the mud, where they crawl but retain their cilia and swim at intervals. They feed at about seven weeks, when ten chætigerous segments are developed, and wander in search of food. There is thus no pelagic larval stage, and it has long been known that the epitoquous stage is also absent from this species. The adult burrows in the mud at ten weeks old.

The early stages and distribution of Octopus vulgaris are the subject of an interesting paper by Dr. W. J. Rees, illustrated by a photograph of the egg strings by Dr. D. P. Wilson, and by drawings of the larvæ by Mr. G. L. Wilkins. The range of the adult octopus is almost confined to the coast of the English Channel, and, since it does not normally breed there, the British population is an immigrant one from warmer waters. Major $\mathrm{H}$. W. Hall kindly lent his motor yacht Manihine for the investigations in the Channel, and young larvæ of the octopus were taken in plankton hauls to the north of the Channel Islands. The planktonic larval life probably lasts from one month to three months. Good weather conditions over a succession of years raise the sea temperature just sufficiently to extend the breeding-range of the octopus, and may result in plagues along the south coasts of England, as occurred in 1899, 1900, 1913, 1922 and 1948.

Two papers on marine algæ appear in the current number. Dr. W. A. P. Black has studied the seasonal variation in the cellulose content of common Scottish Laminariacer. $\mathrm{He}$ found that this increased with depth of immersion and with the season, the two maxima being in spring and autumn, the minimum in June and July. There is more cellulose in the stipe than in the frond. Comparing these results with the Fucacer, similar results were found for Fucus vesiculosus and $F$. serratus, but in Ascophyllum nodosum, $F$. spiralis and Pelvetia canaliculata a more constant content obtains, though $F$. spiralis shows a modification in summer owing to water intake preparatory to gamete shedding.

Dr. M. Knight and Dr. M. Parke have made a careful study of Fucus vesiculosus and $F$. serratus at stations on the west coast of Argyll, the south-west corner of the Isle of Man and south Devon. In the last-named area the range extends to a lower level than in the more northerly stations. Plants of both species normally live three years, but there is a very heavy mortality-rate. Fucus vesiculosus reproduces in spring and summer, $F$. serratus in autumn and winter, large plants producing at least a million eggs. After reproduction the part of the frond bearing the receptacle is shed, and new frondage is developed by dichotomous branching of non-fruiting fronds. The rate of growth varies with the environment and is least in exposed areas; but the rate of forking is encouraged by exposure. The repopulation of cleared areas is very rapid, despite the depredations of gastropod molluses. Cutting of the weed yearly, or twice yearly as in France, produces less frondage than that arising from germlings.

Dr. R. H. Millar describes a new didemnid tunicate, Lissoclinum argyllense, from Scotland, and $\mathbf{M r}$. P. S. B. Digby has investigated the life-histories of nine small planktonic copepods at Plymouth. Six of these are abundant in summer and produce five generations during the year; three commence breeding in August and produce three broods late in the year. Twenty tables of detailed results accompany this paper.

Two welcome news items appear in the report of the Council. The Director's monograph on the medusæ of the British Isles is now in the press, and there is an increase in the number of members of the Marine Biological Association. N. B. EALEs

\section{RADIATION GENETICS}

$T$ HE application of nuclear energy on a large scale brings with it numerous problems, among which the most far-reaching is the biological and particularly the genetical aspect. It had already been shown in 1927 by H. J. Muller that the genes, the physical basis of heredity, can be altered by ionizing radiation and that the rate of the natural mutation can be increased, the magnitude of increase depending on the amount of radiation received. After this great discovery, intensive studies were carried out by geneticists in order to throw light on the mechanism underlying the production by irradiation of various mutational changes in the chromo- 